\title{
Effect of Phytase Enzyme on Organs Growth Performance and Blood Profile of Broiler
}

\author{
Fida Noor Baloch ${ }^{\text {* }}$, Hafeez Noor Baloch ${ }^{2}$, Asad Ullah Khan ${ }^{3}$, Naseebullah Marri Baloch1, \\ Ismail Anwer Baloch1', Nadir Khan Baloch'1, Ayaz Qadir Qambrani' ${ }^{1}$, Abdul Khalique Samejo'
}

\author{
${ }^{1}$ Faculty of Animal Husbandry and Veterinary Sciences Sindh Agriculture University, Tandojam, Pakistan \\ ${ }^{2}$ Shanxi Agricultural University, Taigu, China \\ ${ }^{3}$ University of Veterinary \& Animal Sciences, Lahore, Pakistan \\ Email: *Noorbaloch2@yahoo.com
}

How to cite this paper: Baloch, F.N., Baloch, H.N., Khan, A.U., Baloch, N.M., Baloch, I.A., Baloch, N.K., Qambrani, A.Q. and Samejo, A.K. (2021) Effect of Phytase Enzyme on Organs Growth Performance and Blood Profile of Broiler. Advances in Enzyme Research, 9, 37-49.

https://doi.org/10.4236/aer.2021.93004

Received: May 16, 2021

Accepted: July 12, 2021

Published: July 15, 2021

Copyright $\odot 2021$ by author(s) and Scientific Research Publishing Inc. This work is licensed under the Creative Commons Attribution International License (CC BY 4.0).

http://creativecommons.org/licenses/by/4.0/

\begin{abstract}
Enzymes which are biological catalyst composed of amino acids with minerals and vitamins. The use of enzymes has many benefits in poultry diets include not only enhanced feed conversion and bird performance but also reduced output of excreta problems of environment. The present research work was conducted to evaluate the effect of phytase enzyme on growth performance and blood profile of broiler. Birds were arbitrarily separated into four groups, i.e. Group A (control) was offered $0 \mathrm{~g} / \mathrm{kg}, 0.05 \mathrm{~g} / \mathrm{kg}$ (group B), 0.075 $\mathrm{g} / \mathrm{kg}$ (group C) and $0.025 \mathrm{~g} / \mathrm{kg}$ (group D) phytase enzyme provided in broiler feed. Parameters which were selected in present research work as, feed intake, live body weight, feed conversion ratio, growth performance and blood profile. Results showed that the maximum chicken body weight was noted in group $\mathrm{C}$ and feed intake was minimum in group $\mathrm{C}$, as compared to other groups. Feed conversion ratio was significantly $(p<0.05)$ higher in group $C$, followed by other groups the non-significantly variance founded respectively, the highest weight of liver, gizzard, heart, intestine were noted in treated group C comparatively, highest spleen weight was in group B and in group A (control) the minimum weight of spleen was noted and the average blood profile of broiler chicks in different groups, the white blood cells was significantly higher in group D followed by group A, group B and C. Red blood cells was significantly $(\mathrm{P}<0.05)$ better in group $\mathrm{C}$. Haemoglobin was significant differences in different groups of trial. A significant $(P<0.05)$ difference in Packed cells volume in group A followed by group $\mathrm{B}, \mathrm{C}$ and $\mathrm{D}$. Total protein in group A was minimum followed by group B, C and D, respectively. From the present study, it was concluded that supplementation of $0.075 \mathrm{~g} / \mathrm{kg}$ phytase enzyme has a better effect on growth performance and blood profile of broiler.
\end{abstract}




\section{Keywords}

Broiler Birds, Phytase Enzyme, Growth Performance and Blood Profile of Broiler

\section{Introduction}

The poultry sector one of the highest energetic sections in different organized of the industries of agriculture in Pakistan. The industries of poultry are facing some problems in early growth and active biological activities as per the requirement of the market for enhancing the socio-economic status of the poultry oriented community in the under developing country. The cost amount of feed to a significant proportion of comprehensive livestock production system [1]; according to a report that, cost of feed represents up to $60 \%-80 \%$ of the whole broiler chicken production cost [2]; poultry required enzymes which help in fed breakdown because chicken have not enzyme for fiber break down. Enzymes which are biological catalyst composed of amino acids with minerals and vitamins. The using of enzyme have many benefits in poultry diets include not only enhanced feed conversion and bird performance but also reduced output of excreta problems of environment. It is common practice to name enzymes by adding the suffixase and protease which break down protein, pancreatic lipase which splits lipid/fat [3] [4]; in nutrient of poultry the enzyme usage in animal feed has great importance in most of the developing countries in the price of feed ingredients has been a major constriction. As a consequence nonconventional feed ingredients and cheaper have to be used which contain higher percentage of insoluble/crude fiber and soluble besides with starch. Non Starch Polysaccharides are polymeric carbohydrates which differ in structure from starch and composition, [5].

In the intestinal tract part of these Non-Starch Polysaccharides is water-soluble which is notorious for forming a gel like viscous consistency, [6]; thus gut performance reducing. Phytase enzyme use in the feed industry enzymes in the feed industry has mostly been used for poultry to neutralize the effects in cereals viscous, polysaccharides. These antinutritive carbohydrates are undesirable, as in the diet they reduce absorption and digestion of all nutrients, especially protein and fat. Phytase enzyme not only increases the availability of phosphate in plants and also decreases pollution of environmental. Several other enzyme products are currently being evaluated in the poultry feed industry to assist in the digestion of starch in early-weaned animals and to neutralize certain antinutritive factors in noncereal feedstuffs. The phytase enzyme reduces the inorganic phosphorus quantity ( $40 \%$ in broilers) which is needed in poultry diet, in environment decreases the excreted amount makes more phosphorus available for the bird Simons, [7]; the importance of enzyme using in animal feed. Recently, considerable attention has been shown as a feed phytase enzyme in combination 
with poultry feed. The current mission was scheduled to carry out the influence of partial replacement of sunflower with phytase enzyme on nutrient digestibility of broiler. Phytase enzymes are produced commercially for utilization and improve nutrient digestibility added to poultry feeds. In many others scientists and scholars' research focused on the testing of efficacy and identification of the former for use of Phytase enzyme in the animal feed industry ability to hydrolyze Phytic acid in the gastro intestinal tract [2b]; according to researcher that phytase enzyme has been hard to achieve native microbial phytase enzymes for poultry use [8]; by some processes such as Thermo protective and genetic transformation is an effort to attain these favorite characteristics where, several microbial phytase have been changed [9]; there are much more phytase enzymes which are derived from various types of micro-organisms (fungi and bacteria) and commercially available to the poultry feed industries [10]; in different population groups of poultry chick blood chemistry profile comparison with nutrient intake might designate the need for adjustment of certain nutrients downward/upward [11].

\section{Material and Methods}

The experiment was carried out at the Poultry Research Unit of the Department of Poultry Nutrition, Sindh agriculture university, Tandojam, Pakistan, with the approval of the Committee for Animal Experiments of the Institution.

\subsection{Phytase for Poultry Feed Industry}

Phytase enzyme which are produced commercially for utilization and improve nutrient digestibility added to poultry feeds. In the poultry feed industry ideal phytase enzyme is acidic $\mathrm{pH}$ unaffected and in the small intestine and stomach, where is cost-effective to produce, phosphorus absorption takes place and high temperatures resistant $\left(65^{\circ} \mathrm{C}-80^{\circ} \mathrm{C}\right)$, through feed pelleting are encountered, Lei X, Stahl C. (2001). In many others scientist and scholar's research focused on the testing of efficacy and identification of the former for use of phytase enzyme in the animal feed industry ability to hydrolyze Phytic acid in the gastro intestinal tract $[2 c]$.

\subsection{Microbial Phytase Enzyme Activity Sites}

In poultry the site activity of microbial phytase enzyme at tract of poultry gastro intestinal sections. In proventriculus and crop followed by the jejunum and duodenum of poultry have greater activity of a microbial phytase (fungal phytase).

\subsection{Experimental Birds and Housing}

Two hundred day-old Ross chicks (Gallus gallus domesticus) were purchased from a commercial distributor hatchery of Hyderabad. After initial weight the chicks were first brooded together on deep litter system for one week. Chicken were arbitrarily separated in four was offered $0 \mathrm{~g} / \mathrm{kg}$ group A (control), $0.05 \mathrm{~g} / \mathrm{kg}$ 
(group B), $0.075 \mathrm{~g} / \mathrm{kg}$ (group C) and $0.25 \mathrm{~g} / \mathrm{kg}$ (group D) phytase enzyme provided in broiler feed. Each group were consisted of 50 birds these are presented (Table 1).

\subsection{Feed Intake (g)}

Feed was given twice a day, the feed which refused was collected daily to each group chickens ad libitum, Figure 1.

\subsection{Body Live Weight (g/b)}

Before the research work, by electric weight balance chicken were weighed. In every week the birds were randomly selected from each group and weighed during experimental duration, Figure 2.

\subsection{Feed Conversion Ratio (F.C.R)}

To calculate FCR, increasing weight and intake of feed, were noted by following formula;

$$
\text { FCR }=\frac{\text { Total feed consumed }}{\text { Total weight gain }} \times 100
$$

Table 1. Experimental birds design and housing.

\begin{tabular}{ccccc}
\hline Groups & A & B & C & D \\
\hline Supplementation & Basil dites & $0.05 \mathrm{~g} / \mathrm{kg}$ of Feed & $0.075 \mathrm{~g} / \mathrm{kg}$ of Feed & $0.25 \mathrm{~g} / \mathrm{kg}$ of Feed \\
No. of chicks & 50 & 50 & 50 & 50 \\
\hline
\end{tabular}

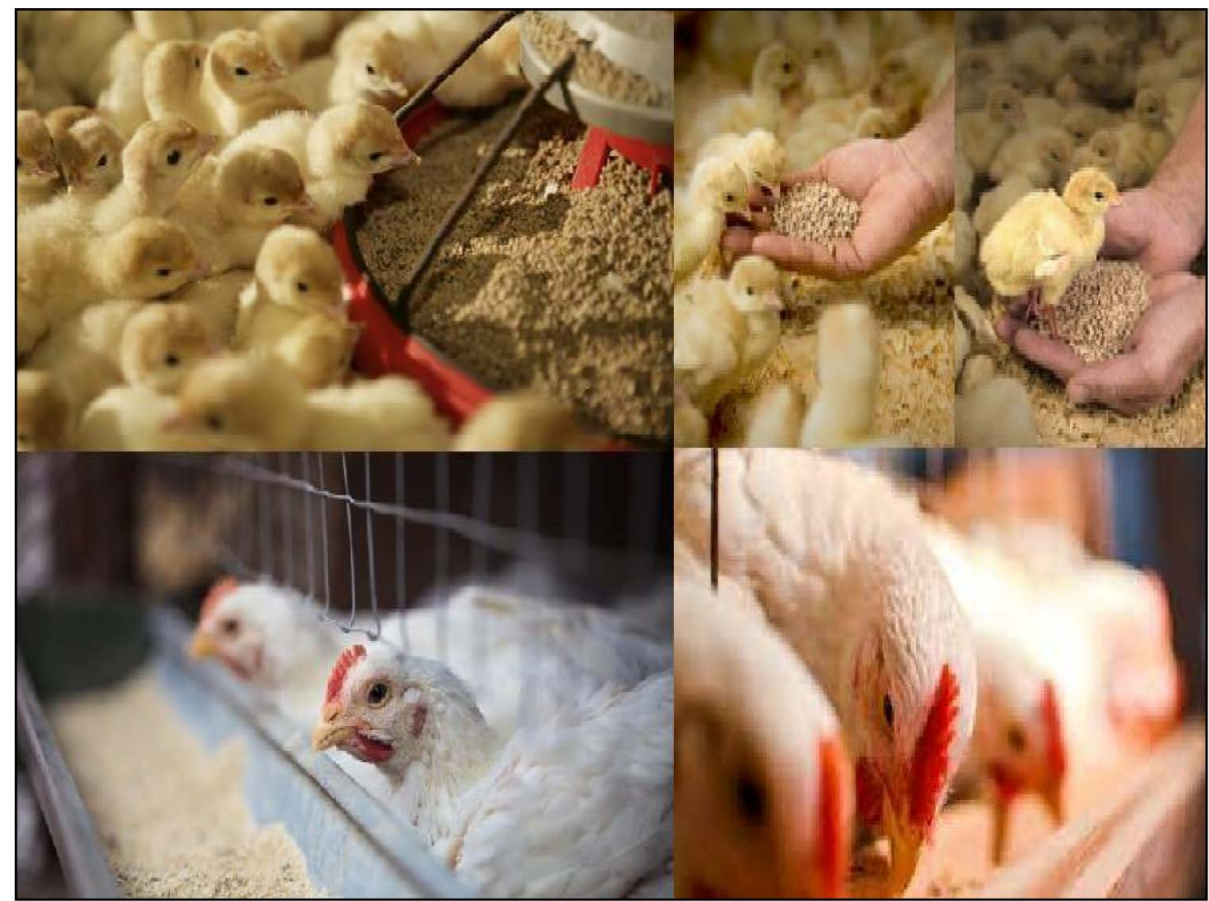

Figure 1. Daily phytase enzyme formulated feed given to broiler birds. 


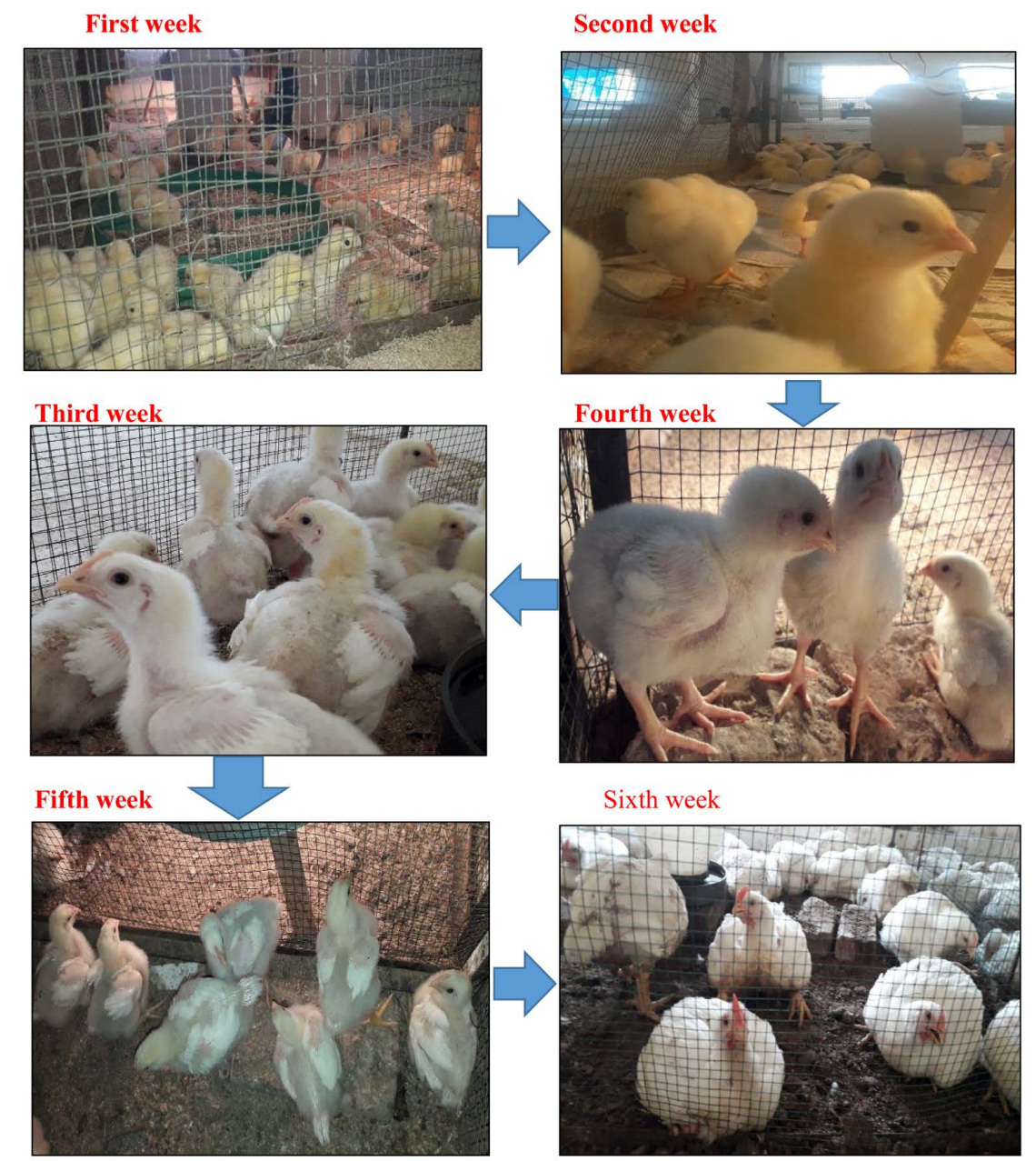

Figure 2. Different stages of live body gain of broiler chicks calculated in first week to sixth weeks.

\section{Ration}

Initially, the chicks were offered commercial starter Formulated ration. The starter ration which was supplied for first three weeks [12]; poultry ration were formulated. The phytase enzyme were supplied in group B, group C and group $\mathrm{D}$ as shown Table 2. In group $\mathrm{C}$ phytase enzyme affects better compared to other groups.

\section{Ration 3.1}

The chicks were offered finisher ration. The finisher ration was given for last three weeks, [12]; poultry ration were formulated, the phytase enzyme were supplied in group B, group C and group D as shown Table 3. In group C phytase enzyme affects better compared to other groups of trial.

\section{Vaccination}

The following vaccination program were adopt according to the approval of Pakistan Poultry Association time to time which are given under schedule during experiment Table 4. 
Table 2. Ingredients and formulation of basal diet (Starter/kg).

\begin{tabular}{|c|c|c|c|c|}
\hline Groups & Ingredients Starter $/ \mathrm{kg}$ & & & \\
\hline & A & B & $\mathrm{C}$ & $\mathrm{D}$ \\
\hline Rice Broken & 31.3 & 31.3 & 31.3 & 31.3 \\
\hline Maize & 30.5 & 30.5 & 30.5 & 30.5 \\
\hline Fish meal & 6.5 & 6.5 & 6.5 & 6.5 \\
\hline Soy bean meal & 24.4 & 24.4 & 24.4 & 24.4 \\
\hline Sunflower meal & 4.8 & 5 & 5 & 5 \\
\hline Molasses & 0.552 & 0.552 & 0.552 & 0.552 \\
\hline Lime stone & 0.554 & 0.554 & 0.554 & 0.554 \\
\hline Salt & 0.2 & 0.25 & 0.25 & 0.25 \\
\hline Soda Bi Carbonate & 0.0111 & 0.0111 & 0.0111 & 0.0111 \\
\hline Premix Vitamin & 0.05 & 0.05 & 0.05 & 0.05 \\
\hline Premix Minerals & 0.05 & 0.05 & 0.05 & 0.05 \\
\hline Dietary Methionine & 0.3155 & 0.3155 & 0.3155 & 0.3155 \\
\hline L-Methionine & 0.05 & 0.05 & 0.05 & 0.05 \\
\hline Lysine Sulphate & 0.3498 & 0.3473 & 0.3423 & 0.3448 \\
\hline L-Threonine & 0.0876 & 0.0876 & 0.0876 & 0.0876 \\
\hline Diclazulin & 0.02 & 0.02 & 0.02 & 0.02 \\
\hline Antibiotics & 0.01 & 0.01 & 0.01 & 0.01 \\
\hline Phytase enzyme & 0 & 0.005 & 0.0025 & 0.075 \\
\hline Over-all & 100 & 100 & 100 & 100 \\
\hline
\end{tabular}

Table 3. Ingredients formulation of diet (Finisher $/ \mathrm{kg}$ ).

\begin{tabular}{|c|c|c|c|c|}
\hline Groups & Ingredients Starter $/ \mathrm{kg}$ & & & \\
\hline & A & $\mathrm{B}$ & $\mathrm{C}$ & $\mathrm{D}$ \\
\hline Rice Broken & 25.6 & 25.6 & 25.6 & 25.6 \\
\hline Maize & 38 & 38 & 38 & 38 \\
\hline Fish meal & 6.5 & 6.5 & 6.5 & 6.5 \\
\hline Soya bean meal & 21.6 & 21.6 & 21.6 & 21.6 \\
\hline Sunflower meal & 5 & 5 & 5 & 5 \\
\hline Molasses & 0.3 & 0.3 & 0.3 & 0.3 \\
\hline Oil & 1.3817 & 1.3817 & 1.3817 & 1.3817 \\
\hline Lime stone & 0.4 & 0.4 & 0.4 & 0.4 \\
\hline Salt & 0.187 & 0.187 & 0.187 & 0.187 \\
\hline Soda Bi Carbonate & 0.0829 & 0.0829 & 0.0829 & 0.0829 \\
\hline Premix Vitamin & 0.05 & 0.05 & 0.05 & 0.05 \\
\hline Premix Minerals & 0.05 & 0.05 & 0.05 & 0.05 \\
\hline Dietary Methionine & 0.312 & 0.312 & 0.312 & 0.312 \\
\hline L-Methionine & 0.05 & 0.05 & 0.05 & 0.05 \\
\hline
\end{tabular}




\section{Continued}

\begin{tabular}{ccccc}
\hline Lysine Sulphate & 0.3756 & 0.3731 & 0.3681 & 0.3706 \\
L-Threonine & 0.1008 & 0.1008 & 0.1008 & 0.1008 \\
Diclazulin & $0-$ & - & - & - \\
Antibiotics & 0.01 & 0.01 & 0.01 & 0.01 \\
Phytase enzyme & 0 & 0.005 & 0.0025 & 0.0075 \\
TOTAL & 100 & 100 & 100 & 100 \\
\hline
\end{tabular}

Table 4. Schedule of vaccination for experimental broiler chicks.

\begin{tabular}{ccc}
\hline Vaccines & Days & Routes \\
\hline I.B + N.D & $1-3$ & Eye Drops \\
IBD vaccine & 12 -Oct & Distal Water \\
H.P. Syndrome & $16-17$ & S/C. $(1 / 2 \mathrm{cc})$ \\
IBD vaccine & 22 & Distal Water \\
Newcastle disease (ND) & 28 & Distal Water \\
\hline
\end{tabular}

Data analysis: in Microsoft excel the data was formulated then further analyzed in One-way analysis of difference (ANOVA) through (statistix 8.1 software) and significant variances were associated using the LSD examination procedure $(\mathrm{P}<0.05)$.

\section{Results and Discussion}

In current study, the blood profile of broiler was observed high in supplementation of phytase enzyme in different treatment groups as compare to control. The live body weight, FCR\%, the highest weight of liver, gizzard, heart, intestine were noted in treated group C comparatively, highest spleen weight was in group B and in group A (control) the minimum weight of spleen was noted.

\subsection{Body Weight}

Analysis of variance showed that there were significant differences between the weight of birds amongst the four treatments $(\mathrm{P}<0.01)$. The results of body weight of birds were noted in treated groups which were supplemented of phytase enzyme compared with un-supplemented group A. The maximum chicken body weight was noted in group $\mathrm{C}$, as compare to group B. The average body weight was further decreased in group D and minimum in group A (control). The presence of phytase enzyme in group $\mathrm{C}$ diet recorded significantly $(\mathrm{P}<0.05)$ the maximum body weight gain Figure 3(A). In instances where phytase enzyme is supplemented, the higher body weight gain may be attributable to an increase in P availability and, maybe feed intake, [13]; the higher CP (crude protein) content may be due to greater content of crude fiber (CF), which may impair nutrient absorption and digestion while the reduced weight gain of broilers fed the control diet group A may be ascribed to low crude protein content of the diet compared to other diets. 


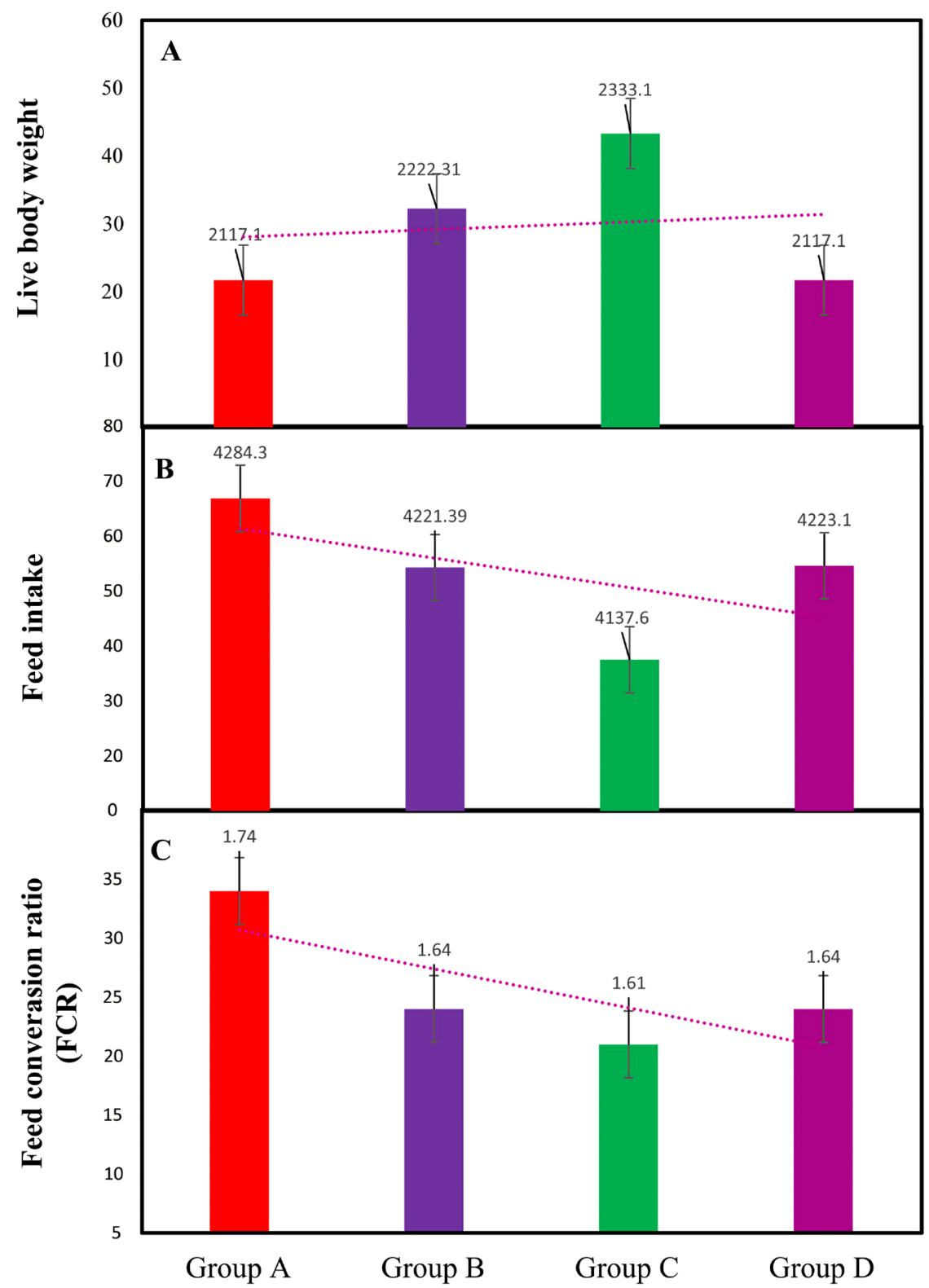

Figure 3. (A) Body Weight. Analysis of variance showed that there were significant differences between the weight of birds amongst the four treatments $(\mathrm{P}<0.01)$. (B) Feed intake. The intake of feed was analysis in different groups of chicks the feed intake was maximum in treatment group A, as compare to group D. (C) FCR \%. The FCR of different groups were examined and the FCR was minimum in treatment group $\mathrm{C}$ and in group A (control) was higher than treatments groups the non-significantly variance founded respectively.

\subsection{Feed Intake}

The intake of feed was analysis in different groups of chicks the feed intake was maximum in group A, as compare to treatments groups. The average intake of feed was further decreased in group C. Feed intake was minimum in group C. The results showed that in group a feed intake was higher than group C, B and $D$, Figure 3(B). In view of investigation the visible increase in feed intake might 
be attributed to increased largeness of the feed and metabolizable energy concentration of the diets. In instances where phytase enzyme is added, to rise in $\mathrm{P}$ availability and, may be feed intake.

\subsection{FCR \%}

The FCR of different groups were examined and the FCR was minimum in treatment group $\mathrm{C}$ and in group B was higher than treatments groups the nonsignificantly variance founded respectively, Figure $3(\mathrm{C})$. This was in agreement with the non-conventional feed stuff often decreases feed cost. This confirms that there is better economic gain by feeding phytase enzyme to broilers since it has the potential of reducing feeding cost of broilers. This supports the conclusion of several researchers that leaf meal supplementation in poultry rations has been proved as means of reducing cost and improving profit margin.

\subsection{Relative Organs Weight (\%)}

From four dietary treatments show (Figure 4), that there is Statistical analysis showed that group $\mathrm{A}$ and group $\mathrm{D}$ were significant difference in relative weight of liver compare to group B and C, while group B and C non-significant different from one another but with increase percentage of phytase enzyme, slightly weight of liver increased. That there were no visible differentiation throughout treatment except for spleen, lung, gizzard their weight was higher significantly in chicks provided phytase enzyme. Such morphological changes, supposedly caused by plant feed additives may provide further information on possible benefits to the digestive tract [14]; these results shows non-significant different in heart weight in different treated groups reported that heart weight slightly increased in different treated groups. The intestine weight of different groups analyzed and the intestine weight of groups D was higher than rest of groups. Such morphological changes in gastrointestinal tissues may provide further information on possible profits to the digestive tract [15]; the increase of villous height of different small intestine segment may be attributed to the role of the intestinal

\section{Organs weight (\%)}

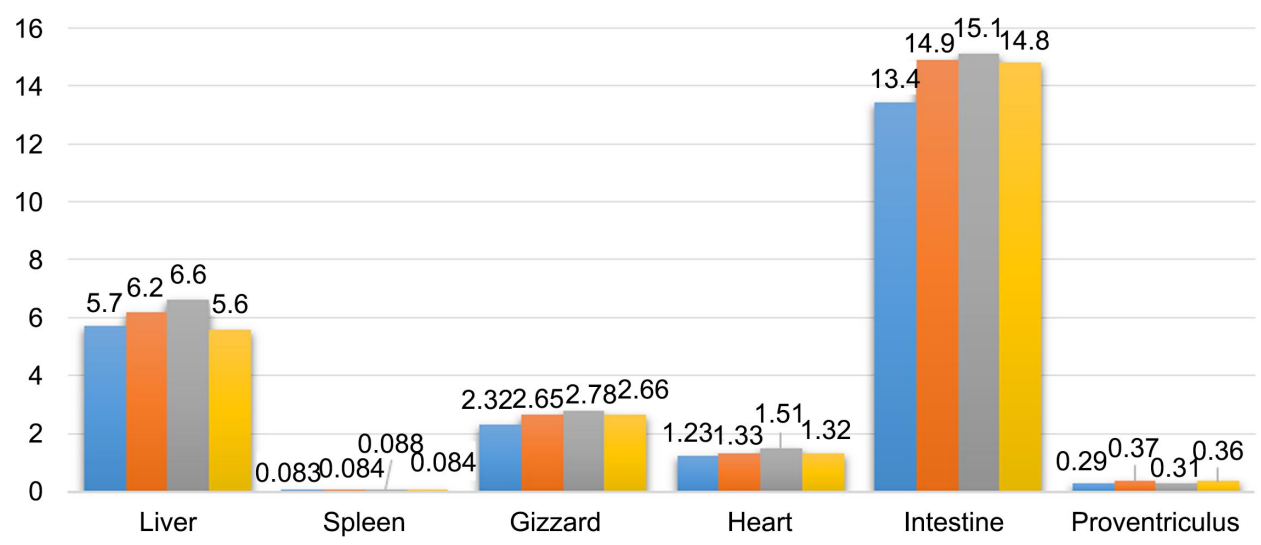

Figure 4. Different organs weight percentage of broiler birds. 
epithelium as a natural barrier against pathogenic bacteria and toxic substances that are present in the intestinal lumen [16].

Level of blood profile of broiler was analysis, where the red blood cells, $\mathrm{He}$ moglobin, total protein, packed cell volume were counted higher in treated $C$ group as related others treated group and control (A), respectively. The level of white blood were counted highest in D group and glucose was highest in (A) group compared to other treatments groups respectively.

\subsection{White Blood Cells Count}

All-pair-wise test shows that in two different groups (B and C) in which the means were non-significantly different from one another while significant different from control group A and group D, respectively. In Figure 5 (1), shows that white blood cells average were counted in group A (control) and treated groups $\left(12.33,12.48,12.46\right.$ and $\left.12.51 \times 10^{3} / \mu \mathrm{L}\right)$, respectively. The comparable WBC of birds suggests that the animals were healthy because decrease in number of WBC below the normal range is an indication of allergic conditions, anaphylactic shock and certain parasitism or presence of foreign body in circulating system [17]; the general non significance of the WBC across treatments indicates that the experimental diets neither impaired nor enhanced the birds' ability to wade off infection.

\subsection{Red Blood Cells Count}

The result in Figure 5 (2), indicate that average red blood cells were count in different groups A, B, C, and group $\mathrm{D}\left(3.16,3.29,3.33\right.$ and $\left.3.19 \times 10^{6} / \mu \mathrm{L}\right)$, respectively. In group $C$ the Maximum red blood cells was counted $\left(3.33 \times 10^{6} / \mu \mathrm{L}\right)$, as compared to group $\mathrm{B}\left(3.29 \times 10^{6} / \mu \mathrm{L}\right)$ and group $\mathrm{D}\left(3.19 \times 10^{6} / \mu \mathrm{L}\right)$. In group $\mathrm{A}$

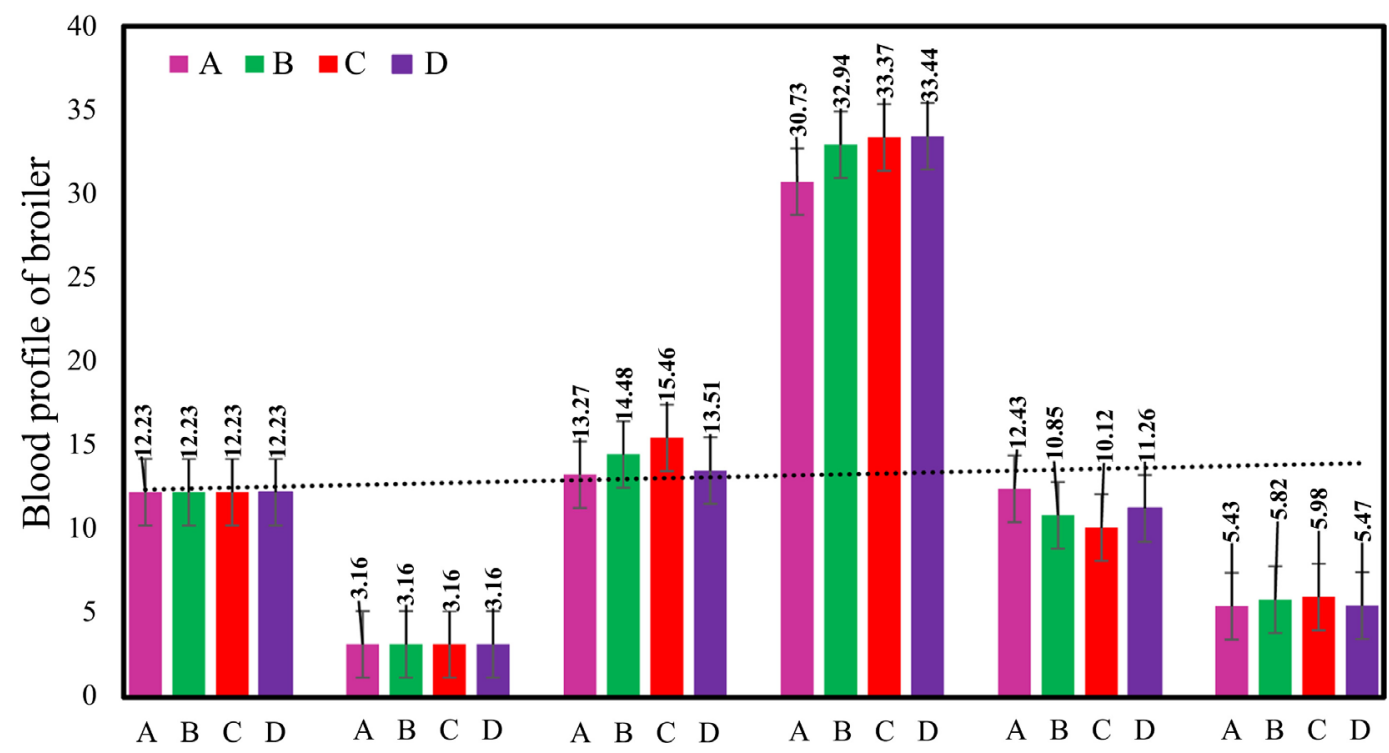

Figure 5. Blood profile of broiler Chicks providing of phytase enzyme in Fed A, B, C, D Indicate A group, $\mathrm{B}$ group, $\mathrm{C}$ group, and D group. 
(control) the average was counted $\left(3.16 \times 10^{6} / \mu \mathrm{L}\right)$. Statistically there were no significant pairwise differences among the means of different groups, respectively. In group $C$ the results shows the higher red blood cells counted than treated and control group A respectively. The values obtained for RBC of birds fed phytase enzyme diets were higher than the range of 3.07 to $7.50 \times 10^{6} / \mathrm{mm}^{3}$ reported by [18]; but within $5-8 \times 10^{6} / \mathrm{mm}^{3}$ reported by [19]; Red Blood Cells (RBC) are responsible for the transportation of oxygen and carbon dioxide in the blood as well as manufacture of haemoglobin hence higher values indicate a greater potential for this function and a better state of health [20].

\subsection{Blood Hemoglobin}

In Figure 5 (3), the results showed that normal blood hemoglobin $(\mathrm{g} / \mathrm{dl})$ was noted in group A (control) and in treated groups (13.27, 14.90, 15.14 and 13.94 $\mathrm{g} / \mathrm{dl}$ ), respectively. In treated group $\mathrm{C}$ the maximum hemoglobin was counted $(15.14 \mathrm{~g} / \mathrm{dl})$. In control group A average hemoglobin was counted $(13.27 \mathrm{~g} / \mathrm{dl})$. Statistically analysis that there were in two groups control group A and group D, where the means were not significantly different from one another while significant from groups B and D, respectively. In group C the results was shows that highest hemoglobin counted than other treated and control groups, respectively.

\subsection{Packed Cell Volume Count}

In Figure 5 (4), the result are showed the average packed cells volume in control and treated groups were counted (30.73, 32.94, 33.73 and 33.44\%) respectively, Maximum packed cell volume was in group C (33.73\%), minimum packed cell volume counted level (30.73\%) was counted in control group (A), where the broiler chicks did not supplied phyase enzyme. Statistically analysis there were in three groups ( $\mathrm{B}, \mathrm{C}$ and $\mathrm{D})$ the means were not significantly different from one another, while significant from group A (control), respectively. The PCV values obtained in this study though it differed significantly among the group was within normal range [21]; the values obtained for all the treatment groups indicate nutritional adequacy of all diets and presence of a toxic factor, since values did not indicate malor under nutrition [22]. PCV is an index of toxicity reduction in the blood usually and suggest presence of a toxic factor which has adverse effect on blood formation [23].

\subsection{Blood Glucose Count}

In Figure 5 (5), the result showed that the average of blood glucose counted in A (control) and treatment groups $(12.43,10.85,10.12$, and $11.26 \mathrm{mmol} / \mathrm{L})$, respectively. In group A (control) the maximum blood glucose level was counted (12.43 $\mathrm{mmol} / \mathrm{L})$, minimum blood glucose count was noted $(10.12 \mathrm{mmol} / \mathrm{L})$ in treated group $\mathrm{C}$, respectively. There were two groups (B and $\mathrm{C}$ ) in which the means were not significantly different from one another while significant from group A and D, respectively. 


\subsection{Total Proteins Count}

In Figure 5 (6), the result showed that the average of total proteins count in treated groups and control (A) group was $(5.43,5.82,5.88$ and $5.47 \mathrm{mg} / \mathrm{dl})$, respectively. In treated group $\mathrm{C}$ the maximum total proteins count was noted, as related to others groups. Minimum total protein count level (5.43) was reported in control (A) group, where the chicks were not provided phyase enzyme. Statistical analysis showed that, there were non-significantly different from one another, respectively.

\section{Conclusion}

From these results, it is concluded that starter broilers could tolerate up to 0.075 $\mathrm{g} / \mathrm{kg}$ phytase enzyme in their diets without adverse effects on their growth performance and blood characteristics.

\section{Acknowledgements}

Many thank the GOD, my family parents, brothers and sisters and especially my great brother Dr. Hafeez Noor Baloch, Ph.D. Scholar, Shanxi Agriculture University, China, for the big support.

\section{Conflicts of Interest}

The authors declare no conflicts of interest regarding the publication of this paper.

\section{References}

[1] Ekenyem, B.U. and Madubuike, F.N. (2001) Non-Ruminant Livestock Production in the Tropics. Gust Chucks Graphics Center, Owerri, 120-145.

[2] Pandey, A., Szakacs, G., Soccol, C.R., Rodriguez-Leon, J.A. and Soccol, V.T. (2001) Production, Purification and Properties of Microbial Phytases. Bioresource Technology, 77, 203-214. https://doi.org/10.1016/S0960-8524(00)00139-5

[3] Classen, H.L. (1996) Successful Application of Enzymes Relies on Knowledge of the Chemical Reation to be Affected and Conditions under Which the Reaction Will Occur. Feed Mix, 4, 22-28.

[4] Classen, H.L. and Bedford, M.R. (1991) The Use of Enzymes to Improve the Nutritive Value of Poultry Feed. In: Haresign, W. and Cole, D.J.A., Eds., Recent Advances in Animal Nutrition, Butterworth, London, 79-102. https://doi.org/10.1016/B978-0-7506-1397-2.50010-1

[5] Morgan, A.J. and Bedford, M.R. (1995) Advances in the Development and Application of Feed Enzymes. Australian Poultry Science Symposium, 7, 109-115.

[6] Ward, N.E. (1995) With Dietary Modifications, Wheat Can Be Used for Poultry. Feedstuffs, 7 Aug, 1416.

[7] Simons, P.C.M., Versteegh, H.A.J., Jongbloed, A.W., Kemme, P.A., Wolters, P., Beudeker, R.F. and Verschoor, G.J. (1990) Improvement of P Availability by Microbial Phytase in Broilers and Pigs. British Journal of Nutrition, 64, 525-540. https://doi.org/10.1079/BJN19900052

[8] Lei, X. and Stahl, C. (2001) Biotechnological Development of Effective Phytases for Mineral Nutrition and Environmental Protection. Applied Microbiology and Bio- 
technology, 57, 474-481. https://doi.org/10.1007/s002530100795

[9] Garret, J.B., Kretz, K.A., O’Donoghue, E., Kerovuo, J., Kim, W., Barton, N.R., Hazlewood, G.P., Short, J.M., Robertson, D.E. and Gray, K.A. (2004) Enhancing the Thermal Tolerance and Gastric Performance of a Microbial Phytase for Use as a Phosphate-Mobilizing Monogastric Feed Supplement. Applied and Environmental Microbiology, 70, 3041-3046. https://doi.org/10.1128/AEM.70.5.3041-3046.2004

[10] Selle, P.H., Ravindran, V., Bryden, W.L. and Scott, T. (2006) Influence of Dietary Phytate and Exogenous Phytase on Amino Acid Digestibility in Poultry. The Journal of Poultry Science, 43, 89-103. https://doi.org/10.2141/jpsa.43.89

[11] Animashahun, R.A., Omoikhoje, S.O. and Bamgbose, A.M. (2006) Haematological and Biochemical Indices of Weaner Rabbits Fed Concentrates and Synedrella nodiflora Forage Supplement. In: Proceedings 11 th Annual Conference of Animal Science Association of Nigeria, Institute of Agricultural Research and Training, Ibadan, 29-32.

[12] Baloch, F.N., Samejo, A.K., Khan Baloch, N., Samejo, Q.A. and Mughal, G.A. (2021) Partial Replacement of Sunflower Meal with Phytase Enzyme on Nutrient Digestibility of Broiler.

[13] Rao, S.V.R., Reddy, V.R. and Reddy, V.R. (1999) Enhancement of Phytate Phosphorus Availability in the Diets of Commercial Broilers and Layers. Animal Feed Science and Technology, 79, 211-222. https://doi.org/10.1016/S0377-8401(99)00020-6

[14] Issa, K.J. and Omar, J.M.A. (2012) Effect of Garlic Powder on Performance and Lipid Profile of Broilers. Open Journal of Animal Sciences, 2, 62-68.

https://doi.org/10.4236/ojas.2012.22010

[15] Windisch, W., Schedle, K., Plitzner, C. and Kroismayr, A. (2008) Use of Phytogenic Products as Feed Additives for Swine and Poultry. Journal of Animal Science, 86, E140-E148. https://doi.org/10.2527/jas.2007-0459

[16] Paul, S.K., Manas, G.H., Mondal, K. and Samanta, G. (2007) Effect of Organi Acid Salt on the Performance and Gut Health of Broiler Chickens. The Journal of Poultry Science, 44, 389-395. https://doi.org/10.2141/jpsa.44.389

[17] Ahamefule, F.O., Obua, B.E., Ukweni, I.A., Oguike, M.A. and Amaka, R.A. (2008) Haematological and Biochemical Profile of Weaner Rabbits Fed Raw or Processed Pigeon Pea Seed Meal Based Diets. African Journal of Agricultural Research, 3, 315-319.

[18] Fudge, C.S. (1999) Laboratory Medicine: Avian and Exotic Pets. WB Saunders, Philadelphia.

[19] Anon (1980) Guide to the Care and Use of Experimental Animal. Vol. 1, Canadian Council of Animal Care, Ottawa, 185-190.

[20] Okeudo, N., Okoli, I.C. and Igwe, G.O.F. (2003) Haematological Characteristics of Ducks (Cairina moschata) of South Eastern Nigeria. Tropicultura, 21, 61-65.

[21] Makkar, H.P.S. and Becker, K. (1996) Plant Toxins and Detoxification Methods to Improve Feed Quality of Tropical Seeds-Review. Asian-Australasian Journal of Animal Sciences, 12, 467-480. https://doi.org/10.5713/ajas.1999.467

[22] Church, J.P., Judd, J.T., Yomg, C.W., Kebay, T.L. and Kim, W.W. (1984) Relationship among Dietary Constituents and Specific Serum Clinical Components of Subjects Eating Self-Selecting Diets. The American Journal of Clinical Nutrition, 40, 1338-1344. https://doi.org/10.1093/ajcn/40.6.1338

[23] Oyawoye, E.O. and Ogunkunle, M. (1998) Chemical Analysis and Biochemical Effects of Raw Jack Beans on Broiler. Nigerin Society of Animal Production, 23, 141-142. 